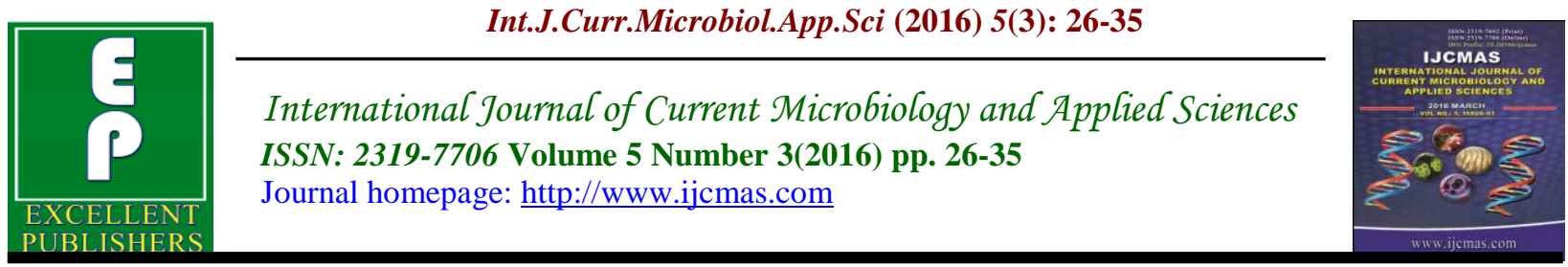

Original Research Article

http://dx.doi.org/10.20546/ijcmas.2016.503.004

\title{
Evaluation of Antioxidant and Antimicrobial Activity of Wine from Various Sources
}

\author{
Sasmita Sabat*, L.N. Chaitra and R. Ranjitha \\ Department of Biotechnology, PES Institute of Technology, 100 Feet Road, \\ Banashankari III Stage, Bangalore 560085, India \\ *Corresponding author
}

\begin{abstract}
A B S T R A C T
Keywords

Wine, Antioxidant property,

Antimicrobial activity, Strawberry, Barley, Rice.

Article Info

Accepted:

07 February 2016

Available Online:

10, March 2016

The aim of present study is to produce wine from four different sourcesrice, barley, grapes and strawberry. The wine produced is determined for its antioxidant properties, total phenolic compounds and antimicrobial activity. The quantification and purification of the wine samples was carried through HPLC. The antioxidant and the efficacy of wine against various microorganisms was verified through disc diffusion method. The assay was performed for four consecutive weeks after the production of wine, and the comparative analysis was made. All the observations suggest that wines have potential effect to overcome the oxidative stress and prevent cellular damage, which is a root cause of various forms of cancer and heart diseases.
\end{abstract}

\section{Introduction}

Wine rich in antioxidant property an alcoholic beverage also is considered as an excellent source for many bioactive compounds like antioxidants, polyophenolic and flavonoids. Reports suggest that wine contains antioxidant power that reduces the oxidative stress and prevents risk for many coronary diseases and cancer (Danila Di Majo et al., 2008). The respirative cycle of oxidative phosphorylation produces free radicals which may attack biological macromolecules like DNA, and cause cell ageing, cardiovascular diseases, and even cancerous tumor growth due to denaturation of single and double strand DNA.
When immune system of an organism fails to rectify the problem then the situation of 'oxidative stress' occurs, which damages the macromolecules present in the body. Consumption of food containing natural antioxidant activity is one of the effective way to overcome the problem (Reşat Apak et al., 2007; Just J.R. et al., 2003; Daroch et al., 2001). Besides these properties, wine also shows significant antimicrobial activity. Recently, the antimicrobial effects on various plant extracts against certain pathogens like Staphylococcus aureus, Candida albicans and E.coli have been reported by a number of researchers. The 
polyphenols like resveratrol, hydroxytyrosol, quercetin and a number of phenolic acids present in the wine shows anti-oxidant, anti-carcinogenic, antiinflammatory and anti-microbial activity (Chrissanthy Papadopoulou et al., 2005; Sandipan Goswami and Subhajit Ray, 2010; Bapat, 2010).

Wine is produced from wide variety of sources. For the winemaker's continuous production of wine throughout the season, its cost effectiveness, easy transportation, storage are essential factors. The quality of the fruit, amount of fermentable sugars, acid content and characteristics flavor provides suitability for wine making (Sandipan Goswami and Subhajit Ray, 2010). Most of the winemaker prefers grape for wine production. The total phenolics in red wine are higher in comparison to the white wine. Wine phenolics are categorized as flavonoid and non-flavonoids. Few fruits with balanced sugar, acid, tannin, nutritive salts as a suitable substrate for the growth of yeast with adequate amount of water are also used for wine production (Robinson Jancis, 2006). The Arunachal Pradesh Horticulture Produce Marketing \& Processing Board (APHM\&PM) in India have funded the project for the wine processing from kiwi fruit. This fruit has high aroma and a refreshing flavor with high acidic nature and sugar almost similar to grapes (Business Standards, 2015). Sucrose if generally added for the fruits that have excess acids can split into fermentable fructose and glucose. In order to maintain the specific gravity of the juice at the initial is too high with water or acidulated water it can be adjusted to the winemaker's target range (Bapat et al., 2010).

In this present study wine was prepared from four different sources; rice, barley, grapes and strawberry under different fermentable conditions. The characterization of both red and white wine was carried out and compared with the commercially available wine for comparative analysis. The quantification and purification of the wine was carried out by HPLC. A comparative evaluation was performed for the estimation of total antioxidant compounds, phenolics concentration and its antimicrobial activity.

\section{Materials and Methods}

\section{Production of Wine from Different Sources}

\section{Processing and Fermentation}

\section{Production of Wine from Black Grapes (Vitis vinifera)}

$250 \mathrm{~g}$ of grapes was weighed and washed by removing the stems with $1 \% \mathrm{HgCl}_{2}$ then with sterile distilled water for 10 minutes. The grapes was soaked in 5\% sodium chloride solution for 15minutes. After the completion of surface sterilization finally it was washed with sterile sterile distilled water. The inoculum was prepared for batch fermentation by homogenizing $250 \mathrm{~g}$ of grapes with $25 \mathrm{~g}$ of sugar and $200 \mathrm{ml}$ of sterile water into an pre-autoclaved wine jar fitted with rubber cork and bent glass tube for the release of $\mathrm{CO}_{2}$. The yeast cell was cultured and maintained for 48 hours in yeast extract, peptone dextrose medium at $27^{0} \mathrm{C}$. The inoculum size of $3 \times 10^{4}$ cells $/ \mathrm{mL}$ was transferred into the fermentation wine jar containing grape juice. The inoculum bottle was incubated for 48 hours at room temperature under slow shaking condition. Later $750 \mathrm{~g}$ of grapes was homogenised along with $50 \mathrm{~g}$ of sugar and $300 \mathrm{ml}$ of water. A pinch of potassium metabisulphite was added. The inoculum was transferred completely to this fermentation bottle and allowed for 
production of wine. The contents are mixed well and incubated for 28 days at room temperature under stationary condition during the incubation period. After the completion of the incubation period of 28 days quantification of antioxidants, total phenolic compounds and other characterization of wine was performed for every week until 4 weeks.

\section{Production of Wine from Strawberries (Fragaria ananassa)}

The strawberries was cleaned by removing the stems and washed under tap water. $250 \mathrm{~g}$ strawberries are then firstly washed with 1 $\% \mathrm{HgCl}_{2}$ then with sterile distilled water. The cleaned fruits was soaked in 5\% sodium chloride solution for 15 minutes washed with sterile distilled water. The strawberries was then weighed and homogenised into pulp in a blender along with $25 \mathrm{~g}$ of sugar and $200 \mathrm{ml}$ of water and transferred into a brown bottle. The same concentration of yeast culture was added as a starter culture to the fruit extract and incubated at $27^{\circ} \mathrm{C}$ for 48 hours under slow shaking condition. For the batch fermentation process same set up was made for the wine production as in the case of grapes. The remaining $750 \mathrm{~g}$ of strawberries are then homogenized into pulp along with $50 \mathrm{~g}$ of sugar and $300 \mathrm{ml}$ of water. A pinch of potassium metabisulphite is added to it and the inoculum is transferred. The contents are mixed well and incubated for 28 days (Sandipan Goswami and Subhajit Ray, 2010) under stationary condition.

\section{Production of Wine from Rice (Oryza sativa) and Barley (Hordeum vulgarae)}

The wine production from rice and barley was performed under two conditions: With sugar and without sugar as the sugar content in both are comparatively lesser than the fruits.

\section{Production of Wine from Rice (Half Boiled Rice)}

The rice grains was cleaned and washed with water properly. It was soaked in clean sterilized water for an overnight and was grind to small particles. In the first setup: $500 \mathrm{~g}$ of partially grinded rice in a 1liter wine jar with single holed rubber cork with a bent glass fitted to release the $\mathrm{CO}_{2}$ during the fermentation and $200 \mathrm{ml}$ of water is taken. To this $17 \mathrm{~g}$ of sugar and same inoculums size of precultured yeast added to the jar. In the second setup: Another 500g of grinded rice was taken similar to the previous set without adding sugar. A pinch of potassium metabisulphite was added to both the jars and the contents were mixed well and incubated for 48 hours under slow shaking condition then transferred to stationary condition for 26 days of incubation.

\section{Production of Wine from Barley}

The barley was cleaned and washed under tap water. It was soaked in clean sterilized water for an overnight and was grind to small particles. Two experimental set up was established-with sugar and without sugar. In the first set $500 \mathrm{~g}$ of partially grinded barley was taken in a 1liter wine jar with $22 \mathrm{~g}$ of sugar and $200 \mathrm{ml}$ of water. The rest $500 \mathrm{~g}$ of grinded barley was set for wine production without sugar. An yeast inoculum of $3 \times 10^{4}$ cells $/ \mathrm{mL}$ was added to both the wine jars and incubated for slow shaking condition for initial 48 hours and later maintained the fermentation process under stationary condition for 02 days. A pinch of potassium metabisulphite is added to both the jars and the contents were mixed well and incubated for 28 days (Sandipan Goswami and Subhajit Ray, 2010). 
Characterization of Standard Wine and Prepared Wine

Estimation of Percentage of Alcohol, Total Acid and Volatile Acid

Estimation of alcohol The concentration of alcohol was estimated by alcoholmetry method using AOAC chart (Table 1).

\section{Estimation of Total Acidity and Volatile Acidity}

$10 \mathrm{ml}$ of the standard wine as well as sample wines was taken in a $100 \mathrm{ml}$ conical flask. Diluted to $1: 1$ ratio by adding $10 \mathrm{ml}$ of distilled water and a few drops of phenolphthalein indicator. This solution was titrated against $0.1 \mathrm{~N} \mathrm{NaOH}$ for the colour appearance from pink to green. The titration was repeated to get concordant values (Ronald et al., 2010). The total acidity and volatile acidity was estimated from the titrated value (Table 1).

Purification and Quantification of Bioactives Compounds of Wine Samples by HPLC

The column used for HPLC system consisted of a C18 RS column (250, 4.6mm ID, S- $5 \mu \mathrm{m}$. $8 \mathrm{~nm}$ ) separation was performed at room temperature. Injection volume was $10 \mu \mathrm{L}$, flow rate set at $1 \mathrm{~mL} / \mathrm{min}$ with $\mathrm{UV}$ detector was carried out at $290 \mathrm{~nm}$. Solvent used were $2 \%$ acetic acid and $0.5 \%$ acetic acid / 50\% acetonitrile. $1 \mathrm{~mL}$ of wine sample was diluted with $5 \mathrm{~mL}$ of methanol and filtered through $0.45 \mu \mathrm{m}$ filter before injection into the $\operatorname{HPLC}^{4}$ (Table 2).

\section{Estimation of Antioxidants Present in Different Wine Samples} Phosphomolybdenum Assay Protocol

An aliquot of $0.3 \mathrm{ml}$ wine sample $(5 \mathrm{mM}$ in $\mathrm{MeOH}$ ) was combined in a 4-ml vial with 3 $\mathrm{ml}$ of reagent solution ( $0.6 \mathrm{M}$ sulfuric acid, $28 \mathrm{mM}$ sodium phosphate and $4 \mathrm{mM}$ ammonium molybdate). The vials was capped and incubated in a water bath at $95^{\circ} \mathrm{C}$ for 90 mins. After the samples had cooled to room temperature, the absorbance of the mixture was measured at $695 \mathrm{~nm}$ against a blank. The antioxidant activity was (Kashif Ghafoor et al., 2011) expressed relative to that of ascorbic acid (Kashif Ghafoor et al., 2011) Table 3.

\section{Antimicrobial Assay (Disc Diffusion Method)}

The pure bacterial and fungal culture was inoculated in a freshly prepared nutrient broth and potato dextrose broth respectively. The inoculated broth was incubated until the $\mathrm{OD}$ at $620 \mathrm{~nm}$ reaches 0.7 . The cultures from the broth was swabbed on a Mueller Hinton agar plate for bacteria and potato dextrose agar plate for fungal culture. The discs with wine samples of various concentrations was placed on the petri plates with swabbed cultures using sterile forceps. The plates was incubated for $24 \mathrm{hrs}$ for bacterial culture and 3 days for fungal culture. After the completion of incubation period the zone of inhibition was measured and compared with standards (Zahid Hussain, 2011) Kirby Bauer Chart The antimicrobial activity shown by different wine samples for microbial cultures with the zone of inhibition was compared for different wine samples (Table 4).

\section{Estimation of Total Phenolic Compounds}

The total phenolic compounds was analyzed using Folin Ciocalteau method. A $200 \mu \mathrm{L}$ properly diluted wine sample or standard solution of varying concentrations mixed with $400 \mu \mathrm{L}$ Folin Ciocalteau reagent. The deionized water was used for dilution and control. The solution was diluted to a total volume of $4.6 \mathrm{~mL}$ using deionized water 
followed by thorough mixing. After incubation for $10 \mathrm{~min}$ at room temperature, $1 \mathrm{~mL}$ of $10 \% \mathrm{Na}_{2} \mathrm{CO}_{3}$ solution was added followed by immediate thorough mixing and incubated for $2 \mathrm{hrs}$ at room temperature. The absorbance was read at $765 \mathrm{~nm}$ on a spectrophotometer (Kashif Ghafoor et al., 2011). Gallic acid of $1 \mathrm{mg} / \mathrm{mL}$ was used as the standard and the total phenolic compounds of the samples was expressed in milligram gallic acid equivalent per $\mathrm{mL}$ of wine sample (mg GA/1 mL) (Table 5).

\section{Results and Discussion}

\section{Characterization of Prepared Wine Samples}

The prepared wine samples was characterized by the colour, aroma, flavor, astringency, $\mathrm{pH}$, alcohol percentage, total acid and volatile acid (Table1). The observations after the $3^{\text {rd }}$ till $9^{\text {th }}$ week fermented wines was found as grape wine was light reddish purple color, strawberry wine was pinkish, rice and barley wine (with and without sugar) was creamish white. The $\mathrm{pH}$ of grape and strawberry wine was found to be 4.7 after fermentation whereas $\mathrm{pH}$ was 3 before fermentation. Rice and barley wine (with and without sugar) the $\mathrm{pH}$ was found to be 4.0 after fermentation and $\mathrm{pH} 6$ before fermentation (Table1).

The alcohol concentration ethyl alcohol, propanol, butanol, etc) was estimated by specific gravity method using specific gravity bottle. The specific gravity of all the wine samples was calculated and percentage of alcohol present was estimated using AOAC chart (Table 1).

Total acid in this study was expressed in terms of percentage of Tartaric acid (Table 1) and was calculated by the formula: Total acidity $(\mathrm{TA})=$ Volume of $\mathrm{NaOH}$ added $\mathrm{x}$ Normality of $\mathrm{NaOH} \times 7.5 / 10$.
Volatile acid is expressed in terms of percentage of Acetic acid (Table 1) and is calculated by the formula:Volatile acidity $(\mathrm{VA})=$ Volume of $\mathrm{NaOH}$ added $\mathrm{x}$ Normality of $\mathrm{NaOH} \times 6 / 10$.

Total acid and volatile acid directly effects the color and flavor of wine. Tartaric acid is one of the major acidic material present predominantly in compare to other acids like malic acid, acetic acid etc. and helps in the ageing of the wine. At the same time among the various volatile acids present in the wine acetic acid plays the major role (Wahab et al., 2005).

The tartaric acid in Roselle wine was found to be $0.65 \%$ which is almost close to grape wine in the present study (Arubi et al., 2009). The VA of the Roselle wine showed $0.04 \%$ of acetic acid, where the rice wine prepared with sugar in the present study showed $0.035 \%$ of acetic acid (Table 1). It is observed that grape wine has highest percentage of TA and VA, followed by strawberry, rice (with sugar), rice (without sugar), barley (with sugar) and lastly barley (without sugar).

Reddy et al, in 2005 (Reddy et al., 2005) optimised wine production from six varieties of Mangifer indica $\mathrm{L}$ and it was found that ethanol produced was $7-8.5 \%$, TA (tartaric acid) $0.6-0.8 \%$ and VA (acetic acid) was $0.01-0.2 \% \mathrm{v} / \mathrm{v}$.

In 2009 Soni et $\mathrm{al}^{21}$ reported during the batch process alcohol produced was $12 \%$ with supplementation of ammonium sulphate, potassium dihydrogen phosphate, proline and biotin to hot water extract of Emblica officinalis (Indian gooseberry), but later in a fed batch process the concentration of alcohol was increased to $16.1 \%$.

The formation of various alcohols like ethyl alcohol, n-propanol, n-butanol, isobutanol 
and isoamyl alcohol were formed $9 \% \mathrm{v} / \mathrm{v}$, $33.45, \quad 8.9,58.98 \quad \& 120.67 \quad \mathrm{mg} / \mathrm{L}$ respectively.

Identification of Bioactives and Purification of Prepared Wine Samples by High Performance Liquid Chromatography (HPLC)

The HPLC was performed for all the prepared wine samples in the 5th week of fermentation and the amount of antioxidant present in each sample is calculated, and is expressed in $\mu \mathrm{g} / \mathrm{mL}$. Gallic acid was used as a standard (Table 2).

The result represents that the concentration of antioxidants presents in strawberry was highest $20 \mu \mathrm{g} / \mathrm{mL}$. and for grapes $12 \mu \mathrm{g} / \mathrm{mL}$. and barley with sugar $10 \mu \mathrm{g} / \mathrm{mL}$. . The other samples contained lower concentration of antioxidant.
Estimation of Antioxidants Present in Different Wine Samples by Phosphomolybdenum Assay

The assay was conducted for four consecutive weeks for comparative analysis (Table 3).The amount of antioxidants present in each wine sample was estimated and expressed in terms of $\mu \mathrm{g} / \mathrm{mL}$. Ascorbic acid was used as standard. It was observed that the amount of antioxidants in all the wine samples increases as the weeks for fermentation increase. Strawberry wine showed constant increase in the concentration from $60 \mu \mathrm{g} / \mathrm{mL}$ to $100 \mu \mathrm{g} / \mathrm{mL}$. Grape wine, rice with sugar and barley with sugar were also showed presence of antioxidant very comparatively close to each other. Hence, in the upcoming days huge interest could be shown in the cultivation of strawberries and the production of strawberry wine.

Table.1 Characterization of Prepared Wine Samples After 28 days of Incubation

\begin{tabular}{|l|c|c|c|c|c|c|c|}
\hline Wine samples & Colour & Aroma & Astrigency & pH & $\begin{array}{c}\text { Alchohol } \\
\%\end{array}$ & $\begin{array}{c}\text { Total } \\
\text { Acid\% }\end{array}$ & $\begin{array}{c}\text { Volatile } \\
\text { Acid \% }\end{array}$ \\
\hline Grapes & $\begin{array}{c}\text { Reddish } \\
\text { Purple }\end{array}$ & $\begin{array}{c}\text { Sour } \\
\text { Fruity }\end{array}$ & Moderate & 5 & 14 & 0.71 & 0.056 \\
\hline Strawberries & Pinkish & $\begin{array}{c}\text { Sweet } \\
\text { Fruity }\end{array}$ & Moderate & 5 & 13 & 0.58 & 0.052 \\
\hline $\begin{array}{l}\text { Rice } \\
\text { (with sugar) }\end{array}$ & Creamish & $\begin{array}{c}\text { Fermented } \\
\text { food }\end{array}$ & High & 4 & 13 & 0.27 & 0.039 \\
\hline $\begin{array}{l}\text { Rice } \\
\text { (without sugar) }\end{array}$ & Creamish & $\begin{array}{c}\text { Fermented } \\
\text { food }\end{array}$ & High & 4 & 11.7 & 0.19 & 0.033 \\
\hline $\begin{array}{l}\text { Barley } \\
\text { (with sugar) }\end{array}$ & Creamish & $\begin{array}{c}\text { Fermented } \\
\text { food }\end{array}$ & High & 4 & 12.5 & 0.35 & 0.038 \\
\hline $\begin{array}{l}\text { Barley } \\
\text { (without sugar) }\end{array}$ & Creamish & $\begin{array}{c}\text { Fermented } \\
\text { food }\end{array}$ & high & 4 & 11.5 & 0.27 & 0.024 \\
\hline
\end{tabular}


Table.2 Amount of Antioxidants (Mg/Ml) Estimated After 28 Days in Different Wine Samples

\begin{tabular}{|l|c|}
\hline \multicolumn{1}{|c|}{ Wine samples } & \multicolumn{1}{c|}{$\begin{array}{c}\text { Amount of } \\
\text { antioxidant }(\boldsymbol{\mu g} / \mathbf{m l})\end{array}$} \\
\hline Grapes & 19 \\
\hline Strawberries & 26 \\
\hline Rice (with sugar) & 8 \\
\hline $\begin{array}{l}\text { Rice } \\
\text { (without sugar) }\end{array}$ & 5 \\
\hline Barley (with sugar) & 15 \\
\hline $\begin{array}{l}\text { Barley } \\
\text { (without sugar) }\end{array}$ & 6 \\
\hline
\end{tabular}

Table.3 Estimation of Antioxidants from Different Wine After the Fermentation (28 Days) Till Four Weeks

\begin{tabular}{|c|c|c|c|c|}
\hline Wine samples & 6th week & $\mathbf{7}^{\text {th }}$ week & $\mathbf{8}^{\text {th }}$ week & $\mathbf{9}^{\text {th }}$ week \\
\hline Rice (with & 12 & 26 & 32 & 40 \\
\hline $\begin{array}{c}\text { Rice } \\
\text { (without sugar) }\end{array}$ & 8 & 10 & 18 & 26 \\
\hline $\begin{array}{c}\text { Barley } \\
\text { (with sugar) }\end{array}$ & 22 & 40 & 46 & 52 \\
\hline $\begin{array}{c}\text { Barley } \\
\text { (without sugar) }\end{array}$ & 18 & 20 & 23 & 30 \\
\hline Grapes & 18 & 28 & 52 & 60 \\
\hline Strawberry & 60 & 66 & 80 & 100 \\
\hline
\end{tabular}

Table.4 Study of Antimicrobial Activity: Zone of Inhibition (In Mm) Measured for the Wine Samples Against E.coli, Pseudomonas aeruginosa and Streptococus pyogenes

\begin{tabular}{|l|c|c|c|}
\hline \multirow{2}{*}{ Wine samples } & \multicolumn{3}{|c|}{ Zone of Inhibition ( mm) } \\
\cline { 2 - 4 } & E.coli & $\begin{array}{c}\text { Pseudomonas } \\
\text { aeruginosa }\end{array}$ & $\begin{array}{c}\text { Streptococus } \\
\text { pyogenes. }\end{array}$ \\
\hline Grapes & 23 & 19 & 15 \\
\hline Strawberries & 21 & 17 & 12 \\
\hline Rice (with sugar) & 18 & 16 & 15 \\
\hline Rice (without sugar) & 13 & 15 & 11 \\
\hline Barley (with sugar) & 14 & 10 & 10 \\
\hline Barley (without sugar) & 09 & 7 & 12 \\
\hline
\end{tabular}


Table.5 The Total Phenolic Compound Present in Different Wine Samples

\begin{tabular}{|l|c|}
\hline \multicolumn{1}{|c|}{ Wine samples } & $\begin{array}{c}\text { TOTAL PHENOLICS } \\
(\mathbf{m g} / \mathbf{m l})\end{array}$ \\
\hline Grapes & 1.09 \\
\hline Strawberries & 1.41 \\
\hline Rice (with sugar) & 1.68 \\
\hline $\begin{array}{l}\text { Rice } \\
\text { (without sugar) }\end{array}$ & 0.92 \\
\hline Barley (with sugar) & 2.10 \\
\hline $\begin{array}{l}\text { Barley } \\
\text { (without sugar) }\end{array}$ & 1.96 \\
\hline
\end{tabular}

Sukanda Vichitphan, Kanit Vichitphan and Prapussara Sirikhansaeng, 2007 found that Krachai-Dum wines showed increase in the total phenolic content, flavonoids and total antioxidants as ageing increases but the study also suggests that the antioxidant activity depends on number of factors including the phenolic compounds present in the wine ${ }^{9}$. The research conducted by Korsak Towantakavanit, Yong Seo Par, Shela Gorinstein, 2010, proves that the antioxidant activity of the wine depends on the quality and ripening stages of the fruit choosen and usually increases with increase in fermentation ${ }^{10}$.

\section{Antimicrobial Assay (Disc Diffusion Method)}

Assay was performed against three bacterial strains of E.coli, Pseudomonas aeroginosa, and Streptococcus pyogenes and the zone of inhibition produced by all the wine samples were measured (Table 4). The recent study conducted by Aleksandra N Radovanovićet et al supports the antimirobial activity of the serbian red wine against various strains of bacteria by disc diffusion method ${ }^{11}$.

\section{Estimation of Total Phenolic Compounds}

The total phenolic compounds was estimated by Folin Ciocalteu method. It was observed that similar results like antioxidant concentration, strawberry wine shows the highest even for phenolic content as $1.14 \mathrm{mg} / \mathrm{mL}$. Wine from dried apricot, raisin using $S$. cerevisae were prepared with an fermentation period of 28 days, were found to be rich in Vitamin A, lycopene, carotenes, polyphenols and antioxidants compounds ${ }^{13}$.

\section{References}

Abdel-Hameed, ESS. 2009. Total phenolic contents and free radical scavenging activity of certain Egyptian ficus species leaf samples. Food Chem.,114: 1271-1277.

Aleksandra, N., Radovanović, Branimir, S., Jovančićević, Blaga, C., Radovanović, Tatjana Mihajilov-Krstev, Jelena, B., Zvezdanović. 2012. Antioxidant and antimicrobial potentials of Serbian red wines produced from international Vitis vinifera grape varieties. J. Sci. Food. Agri., 92(10): 2154-2161.

Arubi, P., Alobo, S.U., Offonry. 2009. Characteristics of coloured wine produced from roselle (Hibiscus sabdariffa) calyx extract. J. Inst. Brew., 115(2): 91-94.

Bapat, R.K., Jadhav, S.B., Ghosh, J.S. 2010. Fermentation and characterization of 
apricot raisin wine by s.cerevisiae NCIM 3282. Res. J. Microbiol. 5(11): 1093- 1099.

Business Standards. 2015. Kiwi success may push Arunachal for more fruit wine production. Press Trust of India, May 10.

Chrissanthy Papadopoulou, Kalliopi Soulti, Ioannis G., Roussis. 2005. Potential antimicrobial activity of red and white wine phenolic extracts against strains of staphylococcus aureus, escherichia coli and candida albicans. Food Technol. Biotechnol., 43(1): 41-46.

Danila Di Majo, Maurizio La Guardia, Santo Giammanco, Laura La Neve, Marco Giammanco. 2008. The antioxidant capacity of red wine in relationship with its polyphenolic constituents. Food chemistry., 111:45-49.

Daroch, R., Hoeneisen, M., Gonzalez, C.L., Kawaguchi, F., Salgado, F., Solar, H., Garcia, A. 2001. In vitro antibacterial activity of Chilean red wined against Helicobacter pylori. Microbios., 104(408): 79-85.

Ghalem, B.R., Mohamed, B. 2009. Antimicrobial activity evaluation of the oleoresin oil of Pistacia vera L. Afri. J. Pharm. Pharmacol., 3(3): 9296.

Just, J.R., Daeschel, M.A. 2003. Antimicrobial effects of wine on E.coli 0157:H7 and $S$. typhimurium in a model stomach system. J. Food Sci., 68: 285-290.

Kashif ghafoor, Fahad al-juhaimi, Yong Hee choi. 2011. Effects of grape (Vitis labrusca b.) peel and seed extracts on phenolics, antioxidants and anthocyanins in grape juice. Pak. J. Bot., 43(3): 1581-1586.

Korsak Towantakavanit, Yong Seo Park, Shela Gorinstein. 2010. Bioactivity of wine prepared from ripened and over- ripened kiwifruit. Cent. Eur. J. Bio., 6(2): 205-215.

Reddy, L.V.A., Reddy, O.V.S. 2005. Production and characterization of wine from mango fruit (Mangifera indica L). World $J$ Microbio \& Biotecnol., 21: 1345-1350.

Reşat Apak, Kubilay Guclu, Birsen Demirata, Mustafa Özyürek, Saliha Esin Çelik, Burcu Bektaşoğlu, K., Işı1 Berker, Dilek Özyurt. 2007. Comparative evaluation of various total antioxidant capacityassays applied to phenolic compounds with the CUPRAC assay. Molecules., 12(7): 1496-1547.

Robinson Jancis. 2006. $3^{\text {rd }}$ edition, Oxford university press, London. Oxford Companion of Wine.

Ronald, L., Prior, Xianli, Wu, Karen Schaich, U.S. 2010. Standardized methods for the determination of antioxidant capacity and phenolics in foods and dietary supplements. $J$. Agric. Food Chem., 53: 4290-4302.

Sandipan Goswami, Subhajit Ray. 2010. Studies on the process development for the fermentative production of wine from grape juice concentrate. Int. J. Food Safety, 13: 367-373.

Soni, S.K., Namita Bansal, Raman Soni. 2009. Standardization of conditions for fermentation and maturation of wine from Amla (Emblica officinalis Gaertn.). Matural Product Radiance, 8(4): 436-444.

Sukanda Vichitphan, Kanit Vichitphan, Prapussara Sirikhansaeng. 2007. Flavonoid content and antioxidant activity of krachai-dum wine (Kaempferia parviflora). KMITL Sci. Tech. J. Vol., 7(2): 97-105.

Wahab, O., Okunowo, Rufus, O., Okotore, Akinniyi, A., Osuntok. 2005. The alcoholic fermentative efficiency of indigenous yeast strains of different 
origin on orange juice. Afri. $J$. Biotech., 4(11): 1290-1296.

Zahid Hussain, Pir Mohammad, Sajid Khan

Sadozai, Khalid Mohammed Khan,

Yasmin Nawaz, Shahnaz Perveen.

2011. Extraction of anti-pneumonia fractions from the leaves of sugar beets Beta vulgaris. J. Pharm. Researc., 4(12): 4783-4785.

\section{How to cite this article:}

Sasmita Sabat, Chaitra L.N. and Ranjitha, R. 2016. Evaluation of Antioxidant and Antimicrobial Activity of Wine from Various Sources. Int.J.Curr.Microbiol.App.Sci. 5(3): 2635. doi: http://dx.doi.org/10.20546/ijcmas.2016.503.004 